Minireview

\title{
Latest progress in hydrogen production from solar water splitting via photocatalysis, photoelectrochemical, and photovoltaic-photoelectrochemical solutions
}

\author{
Rengui Li ${ }^{a, b, *}$ \\ a Dalian National Laboratory for Clean Energy, Dalian Institute of Chemical Physics, Chinese Academy of Sciences, Dalian 116023, Liaoning, China \\ b State Key Laboratory of Catalysis, Dalian Institute of Chemical Physics, Chinese Academy of Sciences, Dalian 116023, Liaoning, China
}

\section{A R T I C L E I N F O}

\section{Article history:}

Received 30 August 2016

Accepted 25 September 2016

Published 5 January 2017

\section{Keywords:}

Solar energy utilization

Photocatalysis

Water splitting for hydrogen

production

Charge separation

\begin{abstract}
A B S T R A C T
Hydrogen production via solar water splitting is regarded as one of the most promising ways to utilize solar energy and has attracted more and more attention. Great progress has been made on photocatalytic water splitting for hydrogen production in the past few years. This review summarizes the very recent progress (mainly in the last 2-3 years) on three major types of solar hydrogen production systems: particulate photocatalysis (PC) systems, photoelectrochemical (PEC) systems, and photovoltaic-photoelectrochemical (PV-PEC) hybrid systems. The solar-to-hydrogen (STH) conversion efficiency of $\mathrm{PC}$ systems has recently exceeded $1.0 \%$ using a $\mathrm{SrTiO}_{3}: \mathrm{La}, \mathrm{Rh} / \mathrm{Au} / \mathrm{BiVO}_{4}: \mathrm{Mo}$ photocatalyst, 2.5\% for PEC water splitting on a tantalum nitride photoanode, and reached $22.4 \%$ for PV-PEC water splitting using a multi-junction GaInP/GaAs/Ge cell and Ni electrode hybrid system. The advantages and disadvantages of these systems for hydrogen production via solar water splitting, especially for their potential demonstration and application in the future, are briefly described and discussed. Finally, the challenges and opportunities for solar water splitting solutions are also forecasted.
\end{abstract}

(C) 2016, Dalian Institute of Chemical Physics, Chinese Academy of Sciences. Published by Elsevier B.V. All rights reserved.

\section{Introduction}

The world's energy supply is based predominantly on the use of non-renewable energy resources such as oil, coal, and natural gas. A sustainable, scalable source of energy-dense chemical fuel is urgently needed to ensure the security of our energy supply for future generations [1,2]. Solar energy is the only renewable energy source of sufficient scale to replace fossil fuels and meet rising environmental demand [3,4]. Hydrogen is the cleanest energy with many potential applications, including the powering of nonpolluting vehicles, fuel cells, do- mestic heating systems, and aircraft [5-7]. Additionally, the use of hydrogen as an energy carrier is a long-term option for reducing worldwide $\mathrm{CO}_{2}$ emissions via the hydrogenation of $\mathrm{CO}_{2}$ to obtain high-value hydrocarbons [8-10]. Therefore, using solar energy to produce hydrogen by photocatalytic water splitting is one of the most promising ways to harness its power.

\section{Mechanism of photocatalytic water splitting on a} semiconductor-based photocatalyst

\footnotetext{
* Corresponding author. E-mail: rgli@dicp.ac.cn

This work was supported by the National Basic Research Program of the Ministry of Science and Technology (973 Program, 2014CB239400), the National Natural Science Foundation of China (21501236, 21673230), and Youth Innovation Promotion Association of Chinese Academy of Sciences (2016167).

DOI: 10.1016/S1872-2067(16)62552-4 | http://www.sciencedirect.com/science/journal/18722067 | Chin. J. Catal., Vol. 38, No. 1, January 2017
} 
The water splitting reaction $\left(\mathrm{H}_{2} \mathrm{O} \rightarrow 1 / 2 \mathrm{O}_{2}+\mathrm{H}_{2}\right)$ is an thermodynamical uphill reaction with a net Gibbs free energy of $237 \mathrm{~kJ} / \mathrm{mol}$. Since the work by Fujishima and Honda [11] using rutile $\mathrm{TiO}_{2}$ anode coupled with a platinum cathode for photoelectrochemical water splitting, extensive efforts have been made to construct efficient photocatalyst systems for solar energy utilization. Generally, the overall photocatalytic water splitting reaction on semiconductor-based photocatalysts involves three major steps: (1) electrons and holes are generated inside semiconductor particles by band-gap excitation, (2) the photogenerated electrons and holes are separated and transferred to the surface of the semiconductor, and (3) the photogenerated electrons and holes are trapped by surface active sites (reduction and oxidation co-catalysts) and consumed by catalytic water reduction and oxidation reactions (Fig. 1) [12-15]. The whole process spans more than 10 time orders from the absorption of light for the charge carrier generation to the surface catalytic reactions that produce gas, which is why photocatalytic water splitting is so challenging. Notably, the recombination of photoexcited carriers generally occurs on a very fast timescale alongside these reactions. Therefore, charge separation in the photocatalyst particles and the redox reactions on their surface must proceed within the lifetimes of the photoexcited carriers for successful water splitting [16]. Many useful strategies have been investigated for improving charge separation efficiency in both PC and PEC systems, e.g., constructing a heterojunction at the interfaces of different photocatalysts to form a built-in electronic field that provides a driving force for charge separation $[17,18]$. Such "junction" strategy can also be successfully introduced between different crystalline phases of the same photocatalyst (e.g., anatase and rutile phase $\mathrm{TiO}_{2}, \alpha$ - and $\beta$-phase $\mathrm{Ga}_{2} \mathrm{O}_{3}$ ), named "phase junction" strategy $[19,20]$. For single photocatalysts without "junctions", morphology engineering, spatial charge separation between different exposed facets of semiconductor crystals, and surface modification by proper co-catalysts have been demonstrated to be useful strategies for improving photocatalytic performance $[15,21,22]$.

\section{General solutions for hydrogen production via solar water splitting}

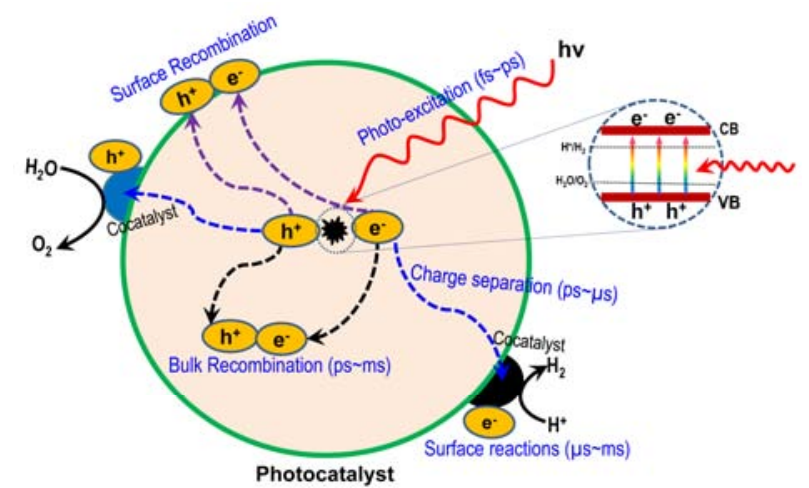

Fig. 1. The mechanism of photocatalytic water splitting on semiconductor-based photocatalyst.
Widely-used solutions for solar hydrogen production mainly fall into three categories: particulate photocatalyst (PC) systems, photoelectrochemical (PEC) systems, and photovoltaic-photoelectrochemical (PV-PEC) hybrid systems (Fig. 2). In PC systems, which are the simplest and lowest cost for potential scalable solar hydrogen production, photocatalyst powders are dispersed in water for hydrogen production under light irradiation. However, the necessity of $\mathrm{H}_{2} / \mathrm{O}_{2}$ gas separation and an enclosed reaction system on a large-scale are disadvantages in PC water splitting processes. The molecular sieving effect of microporous membranes has shown promise for the safe separation of the mixture of $\mathrm{H}_{2}$ and $\mathrm{O}_{2}$ gas. Great progress has been achieved in gas separation by zeolite membranes, and some reviews have highlighted the recent advances in both fundamental science and potential industrial applications [23-25]. The $\mathrm{H}_{2} / \mathrm{O}_{2}$ mixture produced in PC systems may be separated by molecular sieving based on the different kinetic diameters of the two gases $\left(\mathrm{H}_{2}, 2.9 \AA \mathrm{O}_{2}, 3.5 \AA\right)$. In photoelectrochemical systems, the photocatalysts must first be prepared on conductive substrates as electrodes and a small additional bias applied for water splitting. To make a PEC cell work, one or both of the electrodes should be a photoactive semiconductor, in which a space-charge layer forms at the semiconductor/liquid junction. Upon irradiation, photogenerated carriers are separated by the space-charge field and the minority carriers (holes for an n-type photoanode and electrons for a p-type photocathode) travel to the semiconductor-liquid interface for reaction [26]. There is no need for gas separation in PEC water splitting systems because the production of $\mathrm{H}_{2}$ and $\mathrm{O}_{2}$ is spatially separated at different electrode sides. PV-PEC hybrid system for hydrogen production is based on the coupling of highly efficient photovoltaic solar cells and with water electrolysis. PV-PEC systems have many advantages for hydrogen production compared with PEC systems if cost is not a major consideration. For example, for PEC systems the obstacles are a lack of efficient light absorber (for reasonable solar conversion efficiency, the band gap must be less than $2.0 \mathrm{eV}$ ), the corrosion of the semiconductor (thermodynamically, the most useful semiconductors are photochemically unstable in water), and the energetics (the difficulty of matching the semiconductor band-edge energies to the $\mathrm{H}_{2}$ and $\mathrm{O}_{2}$ evolution reactions) $[27,28]$, all of which are not present for PV-PEC water splitting system. For the hydrogen production via solar water splitting, some latest reviews focusing on materials designing, engineering and energy evaluation have been comprehensively summarized [29-32]. In this mini-
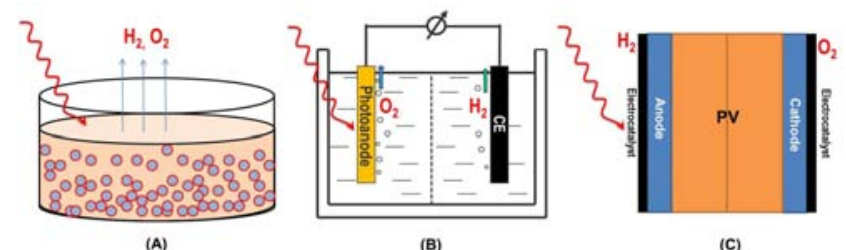

(C)

Fig. 2. The solutions for solar hydrogen via water splitting. (A) Particulate photocatalytic (PC) water splitting system, (B) photoelectrochemical (PEC) water splitting system and (C) photovoltaic-photoelectrochemical hybrid (PV-PEC) system. 
review, I only describe the very latest progress (mainly in the past 2-3 years) from the view of three typical solutions for solar water splitting: PC, PEC and PV-PEC systems.

\section{Water splitting by particulate photocatalyst systems}

To achieve overall water splitting with particulate photocatalyst systems, single-step excitation and two-step excitation (Z-scheme) photocatalysts have been investigated for solar hydrogen production (Fig. 3). In the case of single-step excitation photocatalysts, the band gap of the semiconductor must at least straddle the chemical potentials for proton reduction and water oxidation thermodynamically, however, this is not necessary for a two-step Z-scheme photocatalyst system. In Z-scheme water splitting systems, an electronic mediator is used to connect the hydrogen-evolution and oxygen-evolution redox reactions even though $\mathrm{H}_{2}$ and $\mathrm{O}_{2}$ production takes place on the surface of different photocatalysts.

Many one-step excitation photocatalysts have been investigated in the past few decades for overall water splitting in PC systems. Kato et al. [33] reported that NiO-loaded $\mathrm{NaTaO}_{3}$ doped with lanthanum showed a high photocatalytic activity for water splitting into stoichiometric amounts of $\mathrm{H}_{2}$ and $\mathrm{O}_{2}$ under UV irradiation and an apparent quantum efficiency (AQE) of $56 \%$ at $270 \mathrm{~nm}$. The representative visible-light-responsive photocatalyst for overall water splitting is $\mathrm{Rh} @ \mathrm{Cr}_{2} \mathrm{O}_{3} / \mathrm{GaN}: \mathrm{ZnO}$, which was first reported by Maeda et al. $[34,35]$ with an AQE of up to $5.9 \%$ at a wavelength of $420 \mathrm{~nm}$. More and more photocatalysts for overall water splitting under visible light irradiation have been explored recently (e.g., $\mathrm{In}_{1-x} \mathrm{Ni}_{x} \mathrm{TaO}_{4}$ [36], $\mathrm{LaMg}_{x} \mathrm{Ta}_{1-x} \mathrm{O}_{1+3 x} \mathrm{~N}_{2-3 x}$ [37], nitrogen-doped graphene oxide quantum dots [38], InGaN/GaN nanowires [39]). However, the solar-to-hydrogen (STH) efficiencies of these photocatalysts are still at a very low level (generally less than $0.1 \%$ ) and far below the expectations of industrial applications. Very recently, using a particle transfer method, Wang et al. [40] prepared a photocatalyst sheet for overall water splitting composed of a hydrogen-evolution photocatalyst ( $\mathrm{SrTiO}_{3}: \mathrm{La}, \mathrm{Rh}$ ) and oxygen-evolution photocatalyst $\left(\mathrm{BiVO}_{4}: \mathrm{Mo}\right)$ with Au acting as an electronic shuttle (Fig. 4). The photocatalyst sheet exhibited an extremely high overall water splitting activity with an AQE of $30 \%$ at $419 \mathrm{~nm}$ and STH efficiency exceeding $1 \%$, which is the highest reported for a particulate photocatalyst system. The STH of this system is to expected be further improved by employing photocatalysts with narrower bandgap energies than the short absorption edge wavelengths of $\mathrm{SrTiO}_{3}: \mathrm{La}, \mathrm{Rh}$ and $\mathrm{BiVO}_{4}: \mathrm{Mo}(520$ and $540 \mathrm{~nm}$, respectively). Although the STH efficiency is still far below the estimated industrial requirement of $10 \%$, the work leads us to believe that scalable water splitting using particulate semiconductors is not far from unreachable in the future. One of the greatest obstacles to the future application of PC systems is the cogeneration of $\mathrm{H}_{2}$ and $\mathrm{O}_{2}$ gas, which results in a combustible mixture; suitable engineering controls will be strongly needed to mitigate this safety risk [41,42]. Gas separation in PC systems is a very costly process. It has been estimated that the energy required for gas separation and the dilution of the gas mixture below the explosion limit will use $60 \%$ of the energy stored in the produced hydrogen [42]. Therefore, efficient photocatalysts responsive to visible light, especially to wavelengths larger than $600 \mathrm{~nm}$, are desired because the maximum peak of the solar spectrum is located near this range. Furthermore, the investigation of new gas separation strategies and new materials for $\mathrm{H}_{2} / \mathrm{O}_{2}$ separation (e.g., highly selective molecular sieve membranes for oxygen/hydrogen permeation) has become more and more important for future applications.

Two-step excitation water splitting (Z-scheme) systems that couple a hydrogen-evolution photocatalyst (HEP) and oxygen-evolution photocatalyst via an electronic shuttle (e.g., $\mathrm{IO}_{3}{ }^{-} / \mathrm{I}^{-}, \mathrm{Fe}^{3+} / \mathrm{Fe}^{2+}$ ) have also attracted increasing attention since they were first reported in 2002 [43-46]. The highest $\mathrm{AQE}$ for a Z-scheme water splitting system was recently reported by Chen et al. [47], who constructed a heterojunction between $\mathrm{MgTa}_{2} \mathrm{O}_{6-x} \mathrm{~N}_{y}$ and TaON for efficient charge separation, and it could act as a HEP for Z-scheme water splitting to achieve an AQE of 6.8\%@420 nm. Although the $\mathrm{H}_{2}$ and $\mathrm{O}_{2}$ gases are physically separated on the different sides of Z-scheme systems, their AQE and STH efficiencies are still very low and the highest $\mathrm{AQE}$ has only been improved from $6.3 \%$ (Pt/ZrO $/ \mathrm{TaON}$ as HEP) [48] to $6.8 \%$ in more than 5 years. The visible light responsive photocatalyst, especially for the hydrogen-evolution reaction in the presence of the electronic shuttle, largely determines the efficiency of Z-scheme water splitting.

\section{Water splitting by photoelectrochemical systems}

When semiconductor-based photocatalysts are prepared on an electronic substrate to form photoanodes or photocathodes
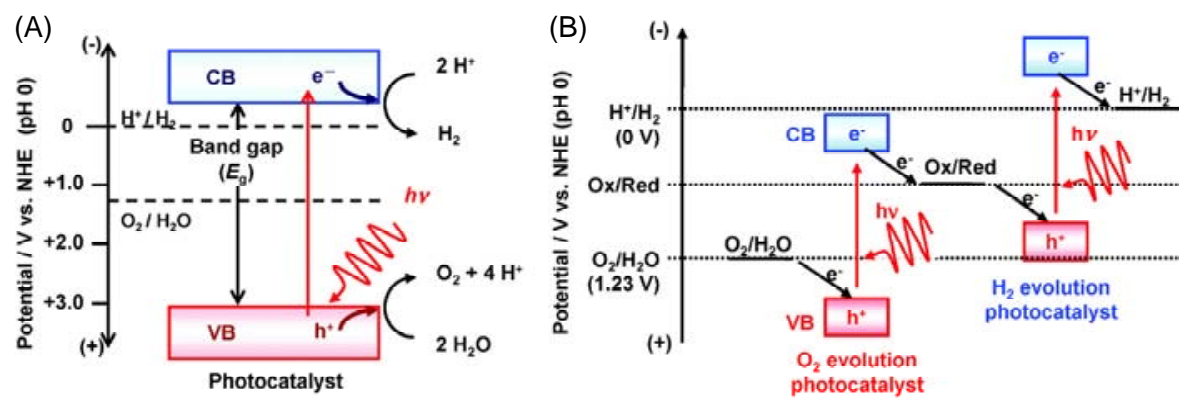

Fig. 3. Energy diagrams of photocatalytic water splitting based on one-step excitation (A) and two-step excitation (Z-scheme) (B). Adapted with permission from reference [16]. Copyright 2014 Royal Society of Chemistry. 
(A)

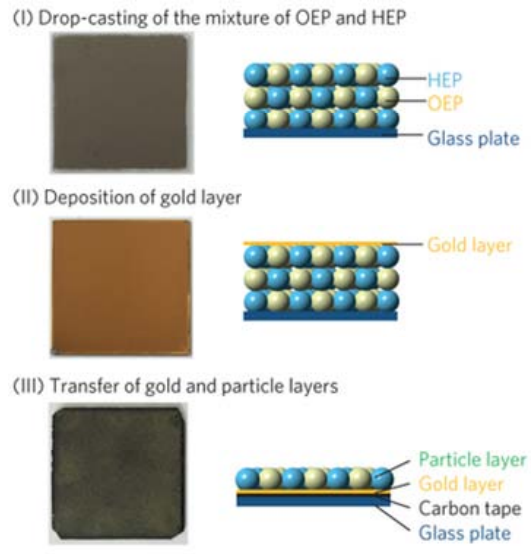

(B)

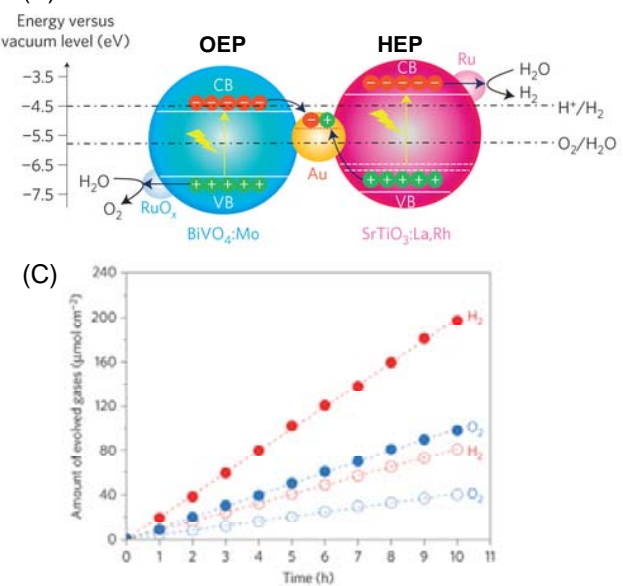

Fig. 4. Photocatalytic water splitting on $\mathrm{SrTiO}_{3}: \mathrm{La}, \mathrm{Rh} / \mathrm{Au} / \mathrm{BiVO}_{4}:$ Mo sheet. (A) Scheme of the preparation by particle transfer method; (B) illustration of charge transfer and surface reactions on the photocatalyst sheet; (C) the performance of overall water splitting on photocatalytic sheet. Adapted with permission from reference [40]. Copyright 2016 Nature Publishing Group.

for PEC water splitting in the presence of an electrolyte solution, electron transfer takes place at the semiconductor-solution interface. This causes the Fermi level to equilibrate with the redox potential of the electrolyte solution and the band bending is consequently produced at the space-charge-layer. Three different configurations of PEC water splitting system have been explored: single photoanode (n-type semiconductor), single photocathode (p-type semiconductor), photoanode and photocathode tandem systems (Fig. 5). Great progress has been achieved in PEC water splitting over the past 2-3 years. Photo-to-current efficiency (ABPE) is generally used to evaluate the conversion efficiency of PEC systems. The ABPE of a PEC system is calculated from the $J-V$ curve of the photoelectrode, where $V_{\text {bias }}$ is the bias applied between the working electrode and counter electrode:

$$
\operatorname{ABPE}(\%)=\left(\frac{J\left(\mathrm{~mA} / \mathrm{cm}^{2}\right) \times\left(1.23-V_{\text {bias }}\right)(\mathrm{V})}{P_{\text {in }}\left(\mathrm{mA} / \mathrm{cm}^{2}\right)}\right)_{\text {AM1.5G }} \times 100 \%
$$

Some popular semiconductors (e.g. $\mathrm{BiVO}_{4}$, $\mathrm{Ta}_{3} \mathrm{~N}_{5}$ ) have attracted great attention for PEC water splitting because of their wide-range light absorption and consequently high theoretical STH efficiency under irradiation with sunlight $\left(9 \%\right.$ for $\mathrm{BiVO}_{4}$ and $15 \%$ for $\mathrm{Ta}_{3} \mathrm{~N}_{5}$, respectively). Choi et al. [49] deposited two oxygen evolution catalysts $(\mathrm{FeOOH}$ and $\mathrm{NiOOH}$ ) on a nanoporous $\mathrm{BiVO}_{4}$ photoanode, which reduced interfacial recombination at the junction between $\mathrm{BiVO}_{4}$ and oxygen evolution catalysts while creating a more favorable Helmholtz layer potential drop at the junction between oxygen evolution catalysts and electrolyte. The resulting $\mathrm{BiVO}_{4} / \mathrm{FeOOH} / \mathrm{NiOOH}$ photoanode achieved a photocurrent density of $2.73 \mathrm{~mA} / \mathrm{cm}^{2}$ at $0.6 \mathrm{~V}$ vs. RHE. Further annealing under $\mathrm{N}_{2}$ atmosphere not only expanded the light-absorption range via $\mathrm{N}$-doping but also improved the charge separation efficiency of the $\mathrm{BiVO}_{4}$ photoanode; the photocurrent was remarkably improved to $4.16 \pm$ $0.41 \mathrm{~mA} / \mathrm{cm}^{2}$ and the $\mathrm{NiOOH} / \mathrm{FeOOH} / \mathrm{N}^{-B_{i V O}} 4$ photoanode showed an ABPE efficiency of up to $2.0 \%$ under a bias of $0.6 \mathrm{~V}$ [50]. Almost at the same time, Kang et al. [51] reported a nanoworm $\mathrm{BiVO}_{4}$ photoanode with bimetallic NiFe as an efficient oxidation co-catalyst, which showed a record ABPE efficiency of up to $2.25 \%$. Таз $\mathrm{N}_{5}$ is a promising candidate for PEC water splitting and many creative studies have been reported on it. Li et al. [52] fabricated a vertically aligned $\mathrm{Ta}_{3} \mathrm{~N}_{5}$ nanorod photoelectrode using a through-mask anodization and nitridation method that yielded a photocurrent density of $3.8 \mathrm{~mA} / \mathrm{cm}^{2}$ at $1.23 \mathrm{~V}$ vs. RHE under AM 1.5G simulated sunlight. The photocurrent was further improved to more than $5.0 \mathrm{~mA} / \mathrm{cm}^{2}$ at 1.23 $\mathrm{V}$ by doping the nanorods with barium and introducing a cobalt phosphate co-catalyst, which yielded a maximum ABPE efficiency of $1.5 \%$ [53]. However, the stability of the Ta3 $\mathrm{N}_{5}$ photoanode is still a challenging issue and the reported systems always rapidly degraded within minutes, and thus new strategies are urgently required to improve this material. Liu et al. [54] reported that ferrihydrite could act as a hole storage layer and permitted sustainable water oxidation at $\mathrm{Ta}_{3} \mathrm{~N}_{5}$ photoanode for at least $6 \mathrm{~h}$ with a benchmark photocurrent of over $5.0 \mathrm{~mA} / \mathrm{cm}^{2}$, which is a breakthrough for PEC water splitting on $\mathrm{Ta}_{3} \mathrm{~N}_{5}$ photoanodes. $\mathrm{A} \mathrm{Ni}(\mathrm{OH})_{x} / \mathrm{MoO}_{3}$ bilayer was also found to be an efficient hole-storage layer that greatly improved the stability of a $\mathrm{Ta}_{3} \mathrm{~N}_{5}$ photoanode to more than $24 \mathrm{~h}$ [55]. Very recently, the authors further coupled a hole-storage layer $\left(\mathrm{Ni}(\mathrm{OH})_{x} /\right.$ ferrihydrite), an electron-blocking layer $\left(\mathrm{TiO}_{2}\right)$, and a
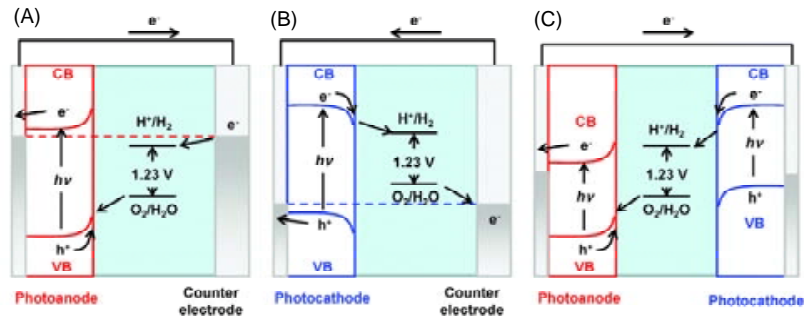

Fig. 5. Three different configurations for PEC water splitting system are explored, single photoanode (n type semiconductor), single photocathode ( $\mathrm{p}$ type semiconductor), photoanode and photocathode tandem system. Adapted with permission from reference [16]. Copyright 2014 Royal Society of Chemistry. 
(A)

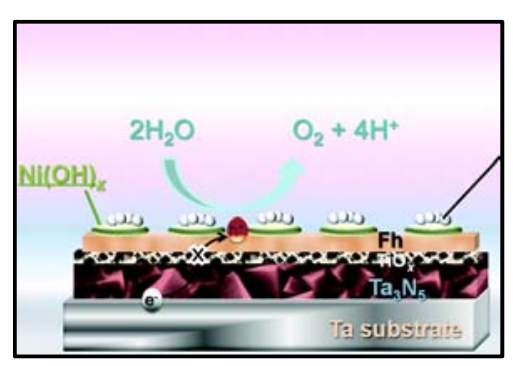

(C)

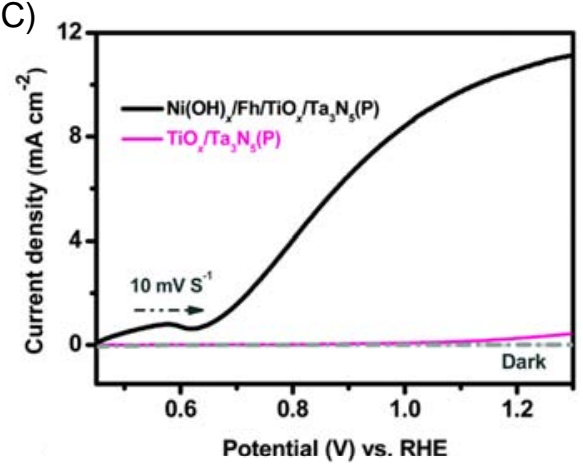

(B)

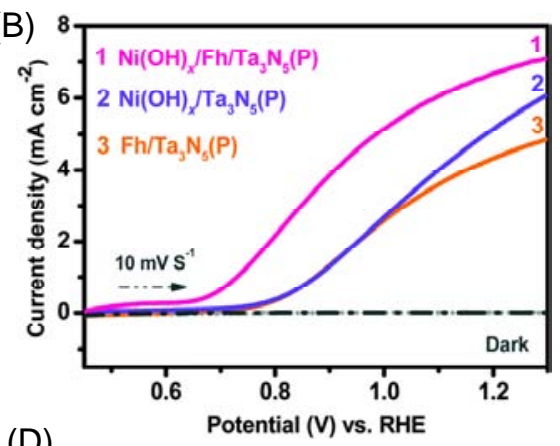

(D)

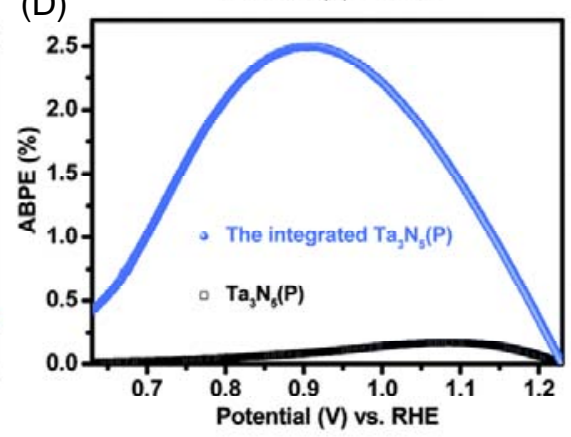

Fig. 6. The performance of PEC water splitting on integrated $\mathrm{Ta}_{3} \mathrm{~N}_{5}$ photoanode with the high STH efficiency. (A) The schematic presentation of the integrated $\mathrm{Ta}_{3} \mathrm{~N}_{5}$ photoanode system; (B) current-potential curves of photoanodes with different hole-storage layers, $\mathrm{Fh} / \mathrm{Ta}_{3} \mathrm{~N}_{5}, \mathrm{Ni}(\mathrm{OH})_{x} / \mathrm{Ta}_{3} \mathrm{~N}_{5}$ and $\mathrm{Ni}(\mathrm{OH})_{x} / \mathrm{Fh} / \mathrm{Ta}_{3} \mathrm{~N}_{5}$; (C) current-potential curves of $\mathrm{Ni}(\mathrm{OH})_{x} / \mathrm{Fh} / \mathrm{TiO}_{x} / \mathrm{Ta}_{3} \mathrm{~N}_{5}$ and $\mathrm{TiO}_{x} / \mathrm{Ta}_{3} \mathrm{~N}_{5}$ photoanodes; (D) the applied bias photon-to-current efficiency (ABPE) of the integrated $\mathrm{Ta}_{3} \mathrm{~N}_{5}$ photoanodes calculated using the related $J-V$ curves. Adapted with permission from reference [56]. Copyright 2016 Royal Society of Chemistry.

Co-complex as an efficient water oxidation co-catalyst to reduce surface electron-hole recombination, which exhibited a record photocurrent of $12.1 \mathrm{~mA} / \mathrm{cm}^{2}$ at $1.23 \mathrm{~V}$ vs. RHE and a ABPE efficiency of more than $2.5 \%$ (Fig. 6) [56]. This is nearly equivalent to its theoretical photocurrent limit under sunlight $\left(12.9 \mathrm{~mA} / \mathrm{cm}^{2}\right)$, suggesting that almost every pair of photogenerated charge carriers in the $\mathrm{Ta}_{3} \mathrm{~N}_{5}$ was efficiently extracted and collected for solar water splitting. However, the challenge that must be overcome in the future for this system is that the onset potential of $\mathrm{Ta}_{3} \mathrm{~N}_{5}$ photoanodes is still too positive $(\sim 0.6$ $\mathrm{V}$ vs. RHE), resulting in a relatively small fill factor, which largely determines the level of efficiency. Other potential semiconductors (e.g. $\mathrm{Fe}_{2} \mathrm{O}_{3}$ [26], $\mathrm{BaTaO}_{2} \mathrm{~N}$ [57], $\mathrm{LaTaO}_{2} \mathrm{~N}$ [58]) that possess good light absorption properties for PEC water splitting have also drawn the attention of many researchers in this field.

Beyond research on photoanodes, some progress has very recently been achieved in the development of photocathodes for PEC water splitting. $\mathrm{Cu}_{2} \mathrm{O}$ is a promising photocathode candidate that possesses a band gap of $2.0 \mathrm{eV}$ and could theoretically deliver a solar to hydrogen conversion efficiency of $18 \%$ for water splitting. In 2011, Paracchino et al. [59] reported that a $\mathrm{Cu}_{2} \mathrm{O}$ photocathode protected by nanolayers of $\mathrm{Al}$-doped zinc oxide and titanium oxide delivered a photocurrent of up to $7.6 \mathrm{~mA} / \mathrm{cm}^{2}$ at a potential of $0 \mathrm{~V}$ vs. RHE for hydrogen evolution. Very recently, Luo et al. [60] fabricated $\mathrm{Cu}_{2} \mathrm{O}$ nanowire array photocathodes for PEC water splitting by combining a high-quality surface $\mathrm{p}-\mathrm{n}$ junction, conformal protection layer, and excellent catalyst decoration, and introducing an innova- tive blocking layer, which delivered a unprecedentedly high photocurrent density of $10 \mathrm{~mA} / \mathrm{cm}^{2}$ and stable operation beyond $50 \mathrm{~h}$, establishing a new benchmark for metal oxide based photoelectrodes.

For future practical application, the scalable fabrication of PEC water splitting photoelectrodes with large areas and stable photoanodes that can be operated for several days or months are required. Because the efficiency of PEC systems is much higher than that of particulate photocatalysis systems and $\mathrm{H}_{2} / \mathrm{O}_{2}$ separation is built-in, PEC water splitting has become one of the most promising solutions for solar energy conversion both in fundamental research and potential applications.

\section{Water splitting by photovoltaic-photoelectrochemical hybrid systems}

For photovoltaic-photoelectrochemical hybrid systems, three approaches have been proposed for coupling the photovoltaic material with the electrolytic water splitting components: integrated PEC devices, partially integrated PEC devices, and non-integrated PEC devices (Fig. 7) [61]. The solar-to-hydrogen efficiency of photovoltaic-photoelectrochemical (PVPEC) systems is the highest among all three kinds of solar hydrogen production system. The first monolithic PV-PEC device for hydrogen production via water splitting was constructed by Khaselev et al. [27] using a GaInP2/GaAs tandem cell in 1998, which showed an STH efficiency more than $10 \%$. Combining a $\mathrm{WO}_{3} / \mathrm{BiVO}_{4}$ photoanode with a double-junction GaAs/InGaAsP solar cell to construct a self-operating integrated photoelectro- 


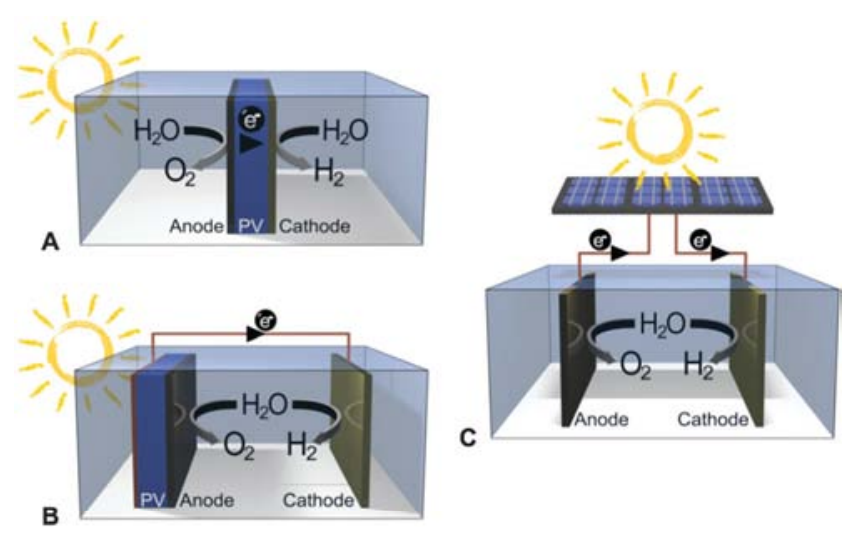

Fig. 7. Three approaches for coupling the photovoltaic material and electrolytic water splitting components. (A) integrated PEC device; (B) partially integrated PEC device; (C) non-integrated PEC device. Adapted with permission from reference [61]. Copyright 2015 Royal Society of Chemistry.

catalysis device resulted in a STH efficiency of up to 8.1\% [62]. Luo et al. [63] reported a hybrid system containing a perovskite solar cell and bimetallic NiFe oxides as electrocatalyst that showed a STH efficiency of $12.3 \%$. The highest efficiency obtained using a PV-PEC strategy was recently achieved by Bonke et al. [61], who fabricated a hybrid system with a multi-junction GaInP/GaAs/Ge solar cell and Ni electrodes for $\mathrm{H}_{2}$ production that delivered a STH efficiency of $22.4 \%$ (Fig. 8). The efficiency of PV-PEC is largely determined by the efficiency of the photovoltaic solar cell and electrocatalyst used in this system. Although the efficiency of hybrid systems has already exceeded the requirements for industrial hydrogen production, the fabrication of solar cells is relatively complicated and expensive, and their cost for solar hydrogen production is far beyond that of hydrogen produced from fossil fuels. Without taking the cost factor into account, PV-PEC systems are the most feasible hydrogen production method for the practical applications. PV-PEC based hydrogen production is expected to be primarily used in aerospace, navigation, and military applications to provide fuel for these special situations.

\section{Conclusions}

A great increase in research activity around solar hydrogen production via water splitting has been achieved in the past
2-3 years. The STH efficiency of particulate photocatalyst systems has now exceeded $1.0 \%$, and this value has been improved to more than $2.5 \%$ and $22.4 \%$ for PEC and PV-PEC water splitting systems, respectively. Challenges and opportunities coexist in solar water splitting for hydrogen production like the two sides of a coin. New semiconductor-based photocatalysts with wide range light absorption, new strategies for improving photogenerated charge separation, and new materials and techniques for gas separation must be explored urgently before scaled-up solar hydrogen production can be realized. Meanwhile, advanced characterization technologies, especially in-situ and ultra-fast spectroscopy methods, that can provide information at very fast time-scales are essential for understanding the mechanism of water splitting reactions. The most exciting thing that has engaged more and more researchers in this field is that there are many important scientific problems that are still unclear, e.g., how charge separation takes place in condensed matter at very fast time-scale, how $\mathrm{H}-\mathrm{O}$ chemical bond breaking and $\mathrm{H}-\mathrm{H}$ and $\mathrm{O}-\mathrm{O}$ chemical bonds forming at the surface of a photocatalyst, and how to accurately simulate charge separation and surface reactions via theoretical calculations. Such fundamental research will help us to deeply understand the mechanisms of and give further guidance for constructing highly-efficient solar energy conversion systems.

\section{References}

[1] K. Alanne, A. Saari, Renew. Sust. Energy Rev., 2006, 10, 539-558.

[2] N. S. Lewis, Science, 2007, 315, 798-801.

[3] M. Asif, T. Muneer, Renew. Sust. Energy Rev., 2007, 11, 1388-1413.

[4] N. S. Lewis, D. G. Nocera, Proc. Nati. Acad. Sci., 2006, 103, 15729-15735.

[5] T. Bak, J. Nowotny, M. Rekas, C. Sorrell, Int. J. Hydrogen Energy, 2002, 27, 991-1022.

[6] T. Bak, J. Nowotny, M. Rekas, C. Sorrell, Int. J. Hydrogen Energy, 2002, 27, 19-26.

[7] M. Momirlan, T. N. Veziroglu, Int. J. Hydrogen Energy, 2005, 30, 795-802.

[8] R. W. Dorner, D. R. Hardy, F. W. Williams, H. D. Willauer, Energy Environ. Sci., 2010, 3, 884-890.

[9] P. G. Jessop, T. Ikariya, R. Noyori, Chem. Rev., 1995, 95, 259-272.

[10] A. E. Ashley, A. L. Thompson, D. O'Hare, Angew. Chem. Int. Ed., 2009, 48, 9839-9843.

[11] A. Fujishima, K. Honda, Nature, 1972, 238, 37-38.

[12] A. L. Linsebigler, G. Lu, J. T. Yates Jr, Chem. Rev., 1995, 95,
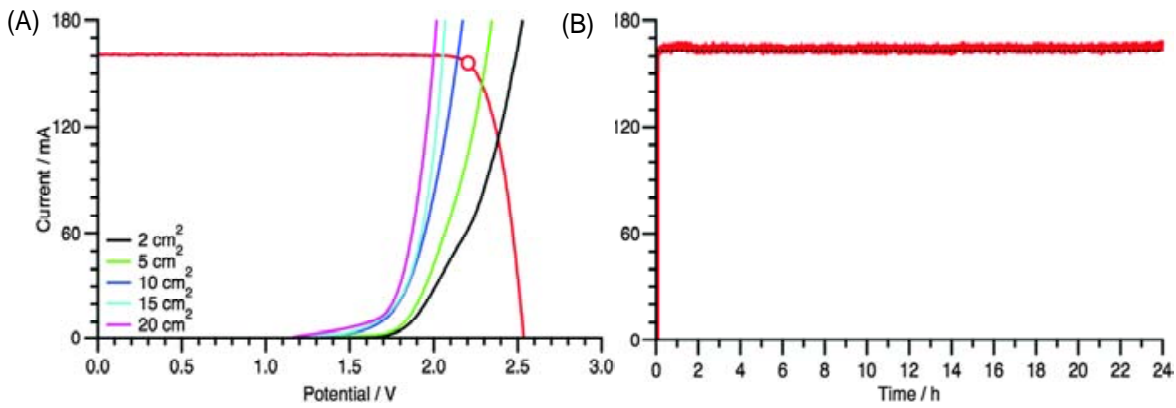

Fig. 8. (A) Comparison of the activity of the Ni foam electrodes and the performance of the GaInP/GaAs/Ge multi-junction solar cell; (B) current generated by the modular system combining the solar cell and a water splitting cell with a STH efficiency of $22.4 \%$. Adapted with permission from reference [61]. Copyright 2015 Royal Society of Chemistry. 


\section{Graphical Abstract}

Chin. J. Catal., 2017, 38: 5-12 doi: 10.1016/S1872-2067(16)62552-4

Latest progress in hydrogen production from solar water splitting via photocatalysis, photoelectrochemical, and photovoltaic-photoelectrochemical solutions

Rengui $\mathrm{Li}^{*}$

Dalian Institute of Chemical Physics, Chinese Academy of Sciences

This minireview summarized some latest progress on three major solutions of hydrogen production via solar water splitting in the past 2-3 years.

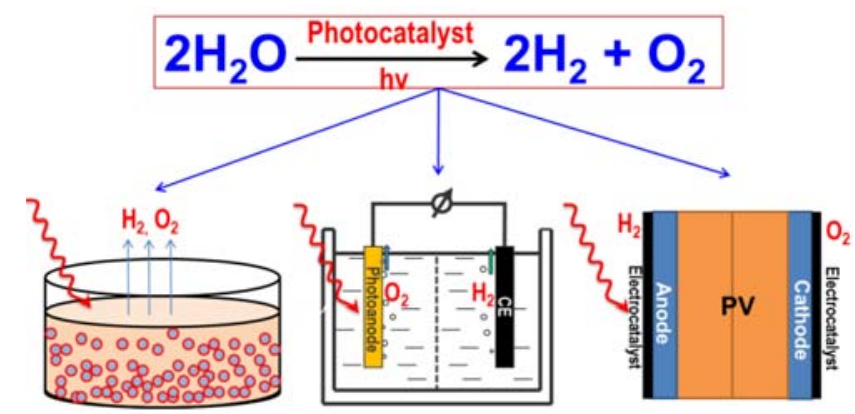

735-758.

[13] X. Chen, S. S. Mao, Chem. Rev., 2007, 107, 2891-2959.

[14] X. Chen, S. Shen, L. Guo, S. S. Mao, Chem. Rev., 2010, 110, 6503-6570.

[15] J. H. Yang, D. E. Wang, H. X. Han, C. Li, Acc. Chem. Res., 2013, 46, 1900-1909.

[16] T. Hisatomi, J. Kubota, K. Domen, Chem. Soc. Rev., 2014, 43, 7520-7535.

[17] H. L. Wang, L. S. Zhang, Z. G. Chen, J. Q. Hu, S. J. Li, Z. H. Wang, J. S. Liu, X. C. Wang, Chem. Soc. Rev., 2014, 43, 5234-5244.

[18] J. S. Jang, H. G. Kim, J. S. Lee, Catal. Today, 2012, 185, 270-277.

[19] J. Zhang, Q. Xu, Z. C. Feng, M. J. Li, C. Li, Angew. Chem. Int. Ed., 2008, 47, 1766-1769.

[20] X. Wang, Q. Xu, M. R. Li, S. Shen, X. L. Wang, Y. C. Wang, Z. C. Feng, J. Y. Shi, H. X. Han, C. Li, Angew. Chem. Int. Ed., 2012, 51, 13089-13092.

[21] R. G. Li, F. X. Zhang, D. E. Wang, J. X. Yang, M. R. Li, J. Zhu, X. Zhou, H. X. Han, C. Li, Nat. Commun., 2013, 4, 1432.

[22] R. G. Li, H. X. Han, F. X. Zhang, D. E. Wang, C. Li, Energy Environ. Sci,, 2014, 7, 1369-1376.

[23] F. Gallucci, E. Fernandez, P. Corengia, M. van Sint Annaland, Chem. Eng. Sci., 2013, 92, 40-66.

[24] C. Feng, K. Khulbe, T. Matsuura, R. Farnood, A. Ismail, J. Membr. Sci. Res., 2015, 1, 49-72.

[25] N. Kosinov, J. Gascon, F. Kapteijn, E. J. M. Hensen, J. Membr. Sci., 2016, 499, 65-79.

[26] K. Sivula, F. Le Formal, M. Grätzel, ChemSusChem, 2011, 4, 432-449.

[27] O. Khaselev, J. A. Turner, Science, 1998, 280, 425-427.

[28] H. Gerischer, Top. Appl. Phys., 1979, 31, 115-172.

[29] L. C. Pop, V. Dracopoulos, P. Lianos, Appl. Surf. Sci., 2015, 333, 147-151.

[30] F. Yilmaz, M. T. Balta, R. Selbaş, Renew. Sust. Energy Rev., 2016, 56, 171-178.

[31] C. Acar, I. Dincer, Int. J. Hydrogen Energy, 2016, 41, 7950-7959.

[32] X. Li, J. G. Yu, J. X. Low, Y. P. Fang, J. Xiao, X. B. Chen, J. Mater. Chem. A, 2015, 3, 2485-2534.

[33] H. Kato, K. Asakura, A. Kudo, J. Am. Chem. Soc., 2003, 125, 3082-3089.

[34] K. Maeda, K. Teramura, D. Lu, T. Takata, N. Saito, Y. Inoue, K. Domen, Nature, 2006, 440, 295-295.

[35] K. Maeda, K. Teramura, K. Domen, J. Catal., 2008, 254, 198-204.

[36] Z. Zou, J. Ye, K. Sayama, H. Arakawa, Nature, 2001, 414, 625-627.

[37] C. Pan, T. Takata, M. Nakabayashi, T. Matsumoto, N. Shibata, Y.
Ikuhara, K. Domen, Angew. Chem. Int. Ed., 2015, 54, 2955-2959.

[38] T. F. Yeh, C. Y. Teng, S. J. Chen, H. Teng, Adv. Mater., 2014, 26, 3297-3303.

[39] M. G. Kibria, H. P. T. Nguyen, K. Cui, S. Zhao, D. Liu, H. Guo, M. L. Trudeau, S. Paradis, A. R. Hakima, Z. Mi, ACS Nano, 2013, 7, 7886-7893.

[40] Q. Wang, T. Hisatomi, Q. Jia, H. Tokudome, M. Zhong, C. Wang, Z. Pan, T. Takata, M. Nakabayashi, N. Shibata, Y. Li, I. D. Sharp, A. Kudo, T. Yamada, K. Domen. Nat. Mater., 2016, 15, 611-615.

[41] B. A. Pinaud, J. D. Benck, L. C. Seitz, A. J. Forman, Z. Chen, T. G. Deutsch, B. D. James, K. N. Baum, G. N. Baum, S. Ardo, H. Wang, E. Miller, T. F. Jaramillo, Energy Environ. Sci., 2013, 6, 1983-2002.

[42] D. M. Fabian, S. Hu, N. Singh, F. A. Houle, T. Hisatomi, K. Domen, F. E. Osterloh, S. Ardo, Energy Environ. Sci., 2015, 8, 2825-2850.

[43] K. Maeda, ACS Catal., 2013, 3, 1486-1503.

[44] K. Sayama, K. Mukasa, R. Abe, Y. Abe, H. Arakawa, J. Photochem. Photobio. A, 2002, 148, 71-77.

[45] A. Kudo, Y. Miseki, Chem. Soc. Rev., 2009, 38, 253-278.

[46] Y. Sasaki, H. Kato, A. Kudo, J. Am. Chem. Soc., 2013, 135, 5441-5449.

[47] S. Chen, Y. Qi, T. Hisatomi, Q. Ding, T. Asai, Z. Li, S. S. K. Ma, F. Zhang, K. Domen, C. Li, Angew. Chem. Int. Ed., 2015, 54, 8498-8501.

[48] K. Maeda, M. Higashi, D. Lu, R. Abe, K. Domen, J. Am. Chem. Soc., 2010, 132, 5858-5868.

[49] T. W. Kim, K. S. Choi, Science, 2014, 343, 990-994.

[50] T. W. Kim, Y. Ping, G. A. Galli, K. S. Choi, Nat. Commun., 2015, 6, 8769.

[51] Y. B. Kuang, Q. X. Jia, H. Nishiyama, T. Yamada, A. Kudo, K. Domen, Adv. Energy Mater., 2016, 6, 8769.

[52] Y. B. Li, T. Takata, D. Cha, K. Takanabe, T. Minegishi, J. Kubota, K. Domen, Adv. Mater., 2013, 25, 125-131.

[53] Y. B. Li, L. Zhang, A. T. Pardo, J. M. González-Calbet, Y. H. Ma, P. Oleynikov, O. Terasaki, S. Asahina, M. Shima, D. Cha, Nat. Commun., 2013, 4, 2566.

[54] G. Liu, J. Shi, F. Zhang, Z. Chen, J. Han, C. Ding, S. Chen, Z. Wang, H. Han, C. Li, Angew. Chem. Int. Ed., 2014, 53, 7295-7299.

[55] G. J. Liu, P. Fu, L. Y. Zhou, P. L. Yan, C. M. Ding, J. Y. Shi, C. Li, Chem. Eur. J., 2015, 21, 9624-9628.

[56] G. J. Liu, S. Ye, P. L. Yan, F. Q. Xiong, P. Fu, Z. L. Wang, Z. Chen, J. Y. Shi, C. Li, Energy Environ. Sci., 2016, 9, 1327-1334.

[57] K. Ueda, T. Minegishi, J. Clune, M. Nakabayashi, T. Hisatomi, H. Nishiyama, M. Katayama, N. Shibata, J. Kubota, T. Yamada, K. Domen, J. Am. Chem. Soc., 2015, 137, 2227-2230. 
[58] P. Arunachalam, A. Al-Mayouf, M. A. Ghanem, M. N. Shaddad, M. T. Weller, Int. J. Hydrogen Energy, 2016, 41, 11644-11652.

[59] A. Paracchino, V. Laporte, K. Sivula, M. Grätzel, E. Thimsen, Nat. Mater,. 2011, 10, 456-461.

[60] J. S. Luo, L. Steier, M. K. Son, M. Schreier, M. T. Mayer, M. Grätzel, Nano Lett., 2016, 16, 1848-1857.

[61] S. A. Bonke, M. Wiechen, D. R. MacFarlane, L. Spiccia, Energy
Environ. Sci., 2015, 8, 2791-2796.

[62] Y. Pihosh, I. Turkevych, K. Mawatari, J. Uemura, Y. Kazoe, S. Kosar, K. Makita, T. Sugaya, T. Matsui, D. Fujita, M. Tasa, M. Kondo, K. Kitamori, Sci. Rep., 2015, 5, 11141.

[63] J. S. Luo, J. H. Im, M. T. Mayer, M. Schreier, M. K. Nazeeruddin, N. G. Park, S. D. Tilley, H. J. Fan, M. Grätzel, Science, 2014, 345, 1593-1596.

\section{太阳能分解水制氢最近进展: 光催化、光电催化及光伏-光电耦合途径$$
\text { 李仁贵a,b,* }
$$ \\ a中国科学院大连化学物理研究所洁净能源国家实验室(筹), 辽宁大连 116023 \\ b 中国科学院大连化学物理研究所催化基础国家重点实验室, 辽宁大连116023}

摘要: 能源是人类生存和发展的物质基础, 太阳能作为最丰富的清洁可再生能源之一, 其开发利用受到了世界范围内的广 泛关注. 通过光催化分解水制氢将太阳能以化学能的形式储存起来不仅能利用太阳能制取高燃烧值的氢能, 同时氢能可 与 $\mathrm{CO}_{2}$ 综合利用结合起来, 在减少碳排放的同时, 生成高附加值的化学品, 实现碳氢资源的优化利用. 光催化分解水制氢 在过去的几年里取得了长足的进步, 本综述从三种研究广泛的太阳能光催化分解水制氢途径 (即光催化、光电催化以及光 伏-光电耦合途径) 入手, 分别简要介绍了太阳能分解水制氢在近几年取得的最新研究进展.

利用纳米粒子悬浮体系进行光催化分解水制氢成本低廉、易于规模化放大, 被认为是未来应用最可行的方式之一, 但 是太阳能转化利用效率还偏低. 最新报道的 $\mathrm{SrTiO}_{3}: \mathrm{La}, \mathrm{Rh} / \mathrm{Au} / \mathrm{BiVO}_{4}: \mathrm{Mo}$ 光催化剂其太阳能到氢能 (STH) 转化效率已超过 了 $1.0 \%$, 相比之前报道的大多数光催化剂体系有了数量级的飞跃, 让人们对太阳能光催化分解水制氢未来的规模化应用 看到了希望. 高效宽光谱响应的光催化剂、高效电荷分离策略、新型高效助催化剂以及气体分离新方法和新材料等, 均是 粉末光催化剂体系研究最为关键的问题; 光电催化分解水在过去 2-3 年内发展迅速, 在一些典型的光阳极半导体材料 (如 $\mathrm{BiVO}_{4}$ 和 $\mathrm{Ta}_{3} \mathrm{~N}_{5}$ 等) 体系上太阳能利用效率超过 $2.0 \%$ 以上. 最新研究发现, 在 $\mathrm{Ta}_{3} \mathrm{~N}_{5}$ 光阳极的研究中, 通过在光电极表面 合理设计和构筑空穴传输层和电子阻挡层等策略, 光电流和电极稳定性均可得到大幅度提升, 光电流大小甚至可接近 $\mathrm{Ta}_{3} \mathrm{~N}_{5}$ 材料的理论极限电流. 如果能进一步在过电位和电极稳定性上取得突破, 该体系的 STH 转化效率还会得到大幅度改 进. 此外, 光阴极的研究也越来越受到了研究者的关注; 光伏-光电耦合体系在三种途径里面太阳能制氢效率最高, 在多个 体系上已超过 $10 \%$ 以上, 最近报道的利用多结 GaInP/GaAs/Ge 电池与 $\mathrm{Ni}$ 电催化剂耦合, 其太阳能制氢效率可达到 $22.4 \%$. 虽然该种制氢途径的效率已超过其工业化应用的要求, 但是光伏电池的成本 (尤其是多结 GaAs 太阳电池) 极大限制了其 大面积规模化应用, 同时还要考虑电催化剂的成本和效率等, 光伏-光电耦合制氢是成本最高的太阳能制氢途径. 需要指出 的是, 光伏-光电耦合制氢有望在一些特殊的领域最先取得实际应用, 如为外太空航天器、远洋航海以及孤立海岛等传统能 源无法满足的地方提供能源供给.

总之, 太阳能分解水制氢研究取得了一系列重要进展, 太阳能制氢效率得到了大幅度提升, 也是目前世界范围内关注 的研究热点之一, 不仅具有强的潜在工业应用背景, 更为基础科学提供了诸多新的研究课题. 这一极具挑战的研究领域, 在先进技术快速发展和基础科学问题认识不断提高的基础上, 不久的将来, 有望在不久的将来在基础科学和应用研究方 面取得重大突破.

关键词: 太阳能利用; 光催化; 水分解制氢; 电荷分离

收稿日期: 2016-08-30. 接受日期: 2016-09-25. 出版日期: 2017-01-05.

*通讯联系人. 电子信箱: rgli@dicp.ac.cn

基金来源：国家重点基础研究发展计划 (973 计划, 2014CB239400), 国家自然科学基金 (21501236, 21673230), 中国科学院青年创 新促进会 (2016167).

本文的英文电子版由Elsevier出版社在ScienceDirect上出版(http://www.sciencedirect.com/science/journal/18722067). 